\title{
Individual social capital as an asset of personal marketing in the job search process
}

\author{
Matias MEMBIELA-POLLÁN, Valentín-Alejandro MARTINEZ- \\ FERNANDEZ, Óscar JUANATEY-BOGA \\ University of A Coruña, Spain
}

\begin{abstract}
:
Aim: The aim of this study is to highlight the role of individual social capital as a personal marketing asset with specific weight in the job search process. The marketing mix instruments are transferred to the analysis of the individual. In this approach, the social network and the attributes of the subject play a specific role in his characteristics as a "product", in his "promotion" and "distribution", and in his "price", which in this case is the salary.
\end{abstract}

Design/Research methods: The methodology used to elaborate this work is based on an exploratory analysis, and seeks to establish a state of the art from the literature on "individual social capital" and "personal marketing". For this, firstly, both concepts are considered, and secondly, the individual social capital as an asset of personal marketing in the job search process is studied, using the tools of the marketing mix (4 P's).

Conclusions/findings: Based on the analysis carried out, we conclude that individual social capital is decisive in the development of personal marketing, whose ultimate goal is to find a job and get a higher income.

Originality/value of the article: The originality of this article lies in applying the tools of the marketing mix to the individual, and considering it as a "product" that wants to be demanded in the labor market; highlighting also the role that individual social capital plays in this process.

Key words: Personal marketing; individual social capital; social network; promotion; employment; income.

JEL Codes: A14, J2, M31.

Contact details: Matias Membiela-Pollán, Campus de Elviña, S/N, CP. 15071 A Coruña, University of A Coruña. E-mail: matias.membiela@udc.es

Received: 13.07.2018, Revised: 24.11.2018, Accepted: 11.12.2018

doi: http://dx.doi.org/10.29015/cerem.752 


\section{Introduction}

This article links two concepts and / or areas of knowledge - social capital and marketing - apparently distant and subject, however, to numerous and relevant links. Issues such as relational marketing, social responsibility, environmental analysis, consumer behavior, word of mouth marketing, organizational structure and culture, social skills... are explained in several researchs under the joint prism of constructs cited.

Our paper focuses on the analysis of the role of individual social capital as an asset of personal marketing with specific weight in the job search process. Individual social capital refers to the network of relationships and personal contacts of the focal subject, and also includes its attributes as a person. For its part, personal marketing employs marketing concepts and tools for the benefit and promotion of the individual's career.

Based on the review of the academic literature, the exploratory analysis that follows uses the categories of operational marketing and marketing mix; thus, the subject is equated to a "product" that has certain characteristics, is promoted by becoming visible, is distributed by positioning itself in a position to be acquired (in the labor market), and has a price (in its case a salary). In this process, the social network of the person and its own attributes - the individual social capital - become an essential asset of the four instruments (4 p's) indicated, which are combined in order to achieve the proposed objective, which is to be sued and acquired by the labor market.

\section{What is social capital}

Social capital is a relatively new variable-concept, which however has had an exponential boom in recent years. This factor completes, together with human capital (referring to education and the experience of individuals), the analysis of endowments presented by the economy, traditionally more concerned with physical capital and natural capital (Sánchez, Pena 2005: 138-139). 
A consensus definition says that social capital is the set of attributes of the social dimension, such as norms and values, trust and social networks that promote cooperative behaviors and favor the functioning of the economy and society in general (Membiela 2016).

It is a multidimensional construct, sometimes called "umbrella concept" and criticized for its ambiguity (Fine 1999; Dasgupta, Serageldin 2000). However, this multidimensionality - it includes many elements that inhabit the "social" field does not diminish its functionality and essentiality (Robison et al. 2001).

The need to outline the concept, how it acts and what its performance is, leads researchers to take advantage of some of the channels offered by literature. These can be structured in the following three approaches:

a) From the individualistic perspective, social capital is an "individual resource" that consists of the networks of relations of the focal subject and their associated instrumental and expressive resources (Bourdieu 1986; Lin 1999).

b) For the communitarian perspective, social capital is a "community resource"; a set of attributes and properties present in the social structure (norms and shared values, particular trust, closure) that facilitate its functioning and collective action (Coleman 1988; Bowles, Gintis 2002).

c) Finally, for the macrosocial perspective, social capital is a "macrosocial and macroinstitutional resource" that, resting on aspects such as citizenship, general trust and social cohesion, lubricates the economy and society in general (Putnam 1993; Knack, Keefer 1997).

In short, the theory of social capital has had, for twenty-five years, a strong growth in terms of scientific and informative articles, essays and monographs, doctoral theses and references published ad hoc. And it has entered to inform great amount of matters and theories; such as economics, sociology, politics, education, family, health, crime, organization theory, technological innovation, and employment (Tsai, Ghoshal 1998: 464; Adler, Kwon 2002: 17; Guiso et al. 2011: 418); question, that of employment, in which we focus on the present text.

This article takes as axis the "individualistic" perspective of social capital. This "microsocial" perspective, also known as "network approach", is very widespread and focuses on the analysis of social capital as a resource of individual character, 
where the actor uses his network of relationships in the achievement of personal goals, both instrumental (income, status, power...) and expressive (welfare, health, recognition, mutual aid...) (Millán, Gordon 2004; Membiela 2016).

The most outstanding reference within this exhibition line is Nan Lin (1999). However, one of the initiators of the theory of social capital, Pierre Bourdieu, in his pioneering article "The Forms of Capital" (1986), already defined social capital as the aggregate of real or potential resources that are linked to the possession of a lasting network of more or less institutionalized relations of knowledge or mutual recognition. In Bourdieu, useful relationships serve to obtain material and symbolic resources; and thus, the social capital possessed by the agent depends on the network of connections it can mobilize and the volume of capital (economic, cultural or symbolic) held by those to which it is connected.

Other researchers have followed this current of social capital theory. Burt (1992) defines social capital as more general friends, colleagues and contacts through which you receive opportunities to use your financial and human capital. Knoke (1999) states that it is the process by which actors create and mobilize their network connections within and between organizations to gain access to the resources of other social actors. For Belliveau, O'Reilly and Wade (1996) consists of the number of people who can be expected to provide support and the resources that those people have at their disposal. And Baker says that social capital is a resource that actors obtain from specific social structures and then use to pursue their interests; is created by changes in the relationship between actors.

If we talk about the social network of the individual, and the resources that can be extracted from it - a question that in the following sections we will link to personal marketing and the job search process, the concept of "individual social capital" becomes interesting, very present in the micro approach of social capital.

Glaeser, Laibson and Sacerdote (2002) refer to individual social capital as those characteristics of the person who, in interaction with other subjects and groups, allow him to reap market and non-market returns. This characterization includes social skills, charisma, status and the quantity and quality of their contacts. In the same vein, Wolleb (2008: 374) points out that the term individual social capital collects the "contacts" that the individual has. Nan Lin (2008: 55) also refers to 
individual social capital as the network of relationships to which the person has access and points out its utility when it comes to achieving some instrumental purposes such as "social mobility". And Pena and Sánchez (2013) write that individual social capital is the set of personal attributes and access networks that facilitate individuals to achieve market and non-market objectives, as a result of interacting with other individuals; the individual social capital is the network of relationships owned by a certain subject and its value lies in the resources that it can extract from them.

\section{What is marketing?}

The word marketing is very present in the collective subconscious, although it should be remembered that it basically consists of a set of principles and practices that seek to increase trade, especially demand. This simple definition can be extrapolated, however, to any type of organization and institution, of a non-business nature (Kotler, Armstrong 2004).

As a discipline, marketing has evolved since the fifties and sixties of the twentieth century, and has varied in its approach; more focused on the product and the transaction in the past, and more focused on the market and on the relationship with customers and intermediaries nowadays (Santesmases 2012).

Marketing is, according to the American Marketing Association (1985), the process of planning and executing the concept, price, promotion and distribution of ideas, products and services to create exchanges that serve to meet the objectives of individuals or organizations.

In this definition, components of strategic marketing and operational marketing are appreciated. The first expresses the "where we are and where we want to go", which includes, with a long-term vision, the analysis of needs, the definition of the reference market, the study of competition and the environment, and the positioning of the brand. The second deals with the "what we have to do to achieve these objectives", which encompasses, with a short and medium term vision, the definition of the chosen segment, the design, execution and control of the marketing plan, the 


\section{Matias MEMBIELA-POLLÁN et al.GA}

marketing mix (product, price, promotion and distribution), and the marketing budget (Lambin et al. 2009).

In short, marketing, in its strategic and operational dimensions, is present in the business field, and in institutions and non-profit organizations. And its applicability has been analyzed in fields as diverse as religion, politics, education, health and tourism (Sheperd 2005).

In the same way that marketing concurs in business and non-business organizations, it can also be applied to the personal field. The individual can and should sell an image and promote a personal and reputational brand that provides positive returns in the labor and non-work areas.

In their article "Branding the Concept of Marketing", Kotler and Levi (1969) broadened the terrain occupied by marketing beyond the sphere of business and pointed out that "personal marketing" is an endemic human activity, present in the employee who deals to impress your boss as in the statesman who seeks the support of the public. With the arrival of mass communication, these authors continue, the commercialization of people has been delivered to professionals. Hollywood stars have their press representatives, political candidates their advertising agencies...

The text in question uses the term personal marketing, although we also include the presence of the words personal branding and self marketing that express similar but not identical meanings (Sheperd 2005).

In a globalized and highly competitive world, marketing skills extrapolated to the person are beneficial in order to promote entrepreneurship, transmit visibility, positioning, and relationship with society and the environment in which the individual develops (Valarezo Paredes 2015; Peters 2000). In this sense and as Sheperd (2005) points out, pure talent alone is not enough to reach the pinnacle of success; personal marketing can give a competitive advantage.

Personal marketing is defined by Kotler (2003) as a new discipline that uses the concepts and tools of marketing to benefit the career and personal experiences of individuals, putting the value of the human being in all its attributes, characteristics and complex structure. While Pérez Ortega (2008) expresses that it consists of, starting from some marked objectives of personal and / or professional life, choosing the most appropriate strategies and tools to achieve these objectives, taking into 
account the reality of the people who live with us and often in competition, and all within a changing environment.

In summary, personal marketing is much more than "selling oneself", although this elocution is embodied in the noblest of forms (Acosta Vera 2006). In the personal marketing, strategic marketing (personal life goals, analysis of our strengths and weaknesses, analysis of the competition and the environment, personal marketing plan) and operational marketing (concrete tools to achieve these objectives) are present.

\section{Individual social capital as an asset of personal marketing in the job search process}

In what follows, the process of active job search is considered and the individual is equated with a product that interrelates with the other tools of operational marketing. The variables of the marketing mix (product, price, promotion, distribution) are interpreted under the prism of personal marketing, being the objective the achievement of the best result in terms of employment and status. In particular, we are interested in the role that individual social capital plays in this process.

\subsection{The product-person}

The product is everything that can be offered in a market for its attention, acquisition or consumption, and that satisfies a desire or a need. The marketing offer, as Kotler and Armstrong (2006) point out, includes people, places, organizations, information and ideas.

The individual is a product available to the demand of the labor market, which has attributes in the form of quality, characteristics and even style and design.

As is logical, "human capital", constituted by education, knowledge, innate aptitudes, competences and experience, has a substantial weight in this point (Cameron, Neal 2005; Acosta Vera 2006); aspects that make the subject more attractive in terms of its characteristics and quality. 
The product-person also tends to be more interesting for the labor market the greater its individual social capital. If the personal attributes (disposition, attitude, ethics-values, social skills, emotional intelligence, self-esteem, group work) are positive, the actual product-person will increase its value (Acosta Vera 2006; Goleman 2010). Likewise, the social network of the individual increases, a priori, access to information and opportunities with which the reference organization can benefit.

\subsection{The promotion and distribution of the product-person}

The promotion is the element of the marketing mix that serves to inform, persuade and remember a market about a product or the organization that sells it, with the hope of influencing the feelings, beliefs or behavior of the reveivers of the promoter action (Stanton et al. 2007).

The characteristics and the quality of the product-person often are not enough to be demanded by the labor market. It should be made known its existence and the benefits it brings; this means to promote or communicate the product (Santesmases 2012).

The promotion can be carried out in different ways. The goal is to create an image, differentiate and position yourself.

At present, online social networks linked to the labor market have become relevant (linkedin, infojobs); although social media in general, and especially twitter, "communicate" the presence of the individual and its value, in the same way that they make known a brand, product or service (Carballar 2011). These networks also affect the perceived image and the reputational capital of the subject (Herrera 2009).

Personal promotion is also linked to participation in professional events, the authorship of blogs, websites and articles on topics related to the area of knowledge; and with the updating of the information through different sources of information (newspapers and magazines, newsletters, official organisms...) (Acosta Vera 2006).

For its part, the distribution relates the product to consumption; its mission is to make the good available to the market, and to do so in a way that stimulates its acquisition (Santesmases 2012). In our case, the individual is the product that can 
meet certain needs of the company as a labor force demanding. The distribution of the product-person encompasses the organizations or relational nodes of the individual, who have, or not, knowledge of their work disposition.

Individual social capital plays a very important role both in the promotion and in the distribution of the product-person. On the one hand, the subject communicates (online or offline) his presence using and / or consolidating their social network (Herrera 2009). On the other hand, he is in a position to be sued, since said network or individual social capital (family, friendships, acquaintances) is a decisive provider of information and opportunities with the potential to affect his employment and status (Granovetter 1973, 1999; Membiela 2016). In this sense, says Acosta Vera (2006), $85 \%$ of employment is generated by small and medium enterprises, and many of them do not use professional selection systems. In addition, the fact that a very significant percentage of workers find employment through personal contacts offers an idea of the role that the personal social network plays in this regard.

\subsection{The price of the product-person}

The price is the amount of money that is charged for a product or service: it is the sum of values that the clients exchange for the benefits of having or using a product (Kotler, Armstrong 2013).

In the case of the product-person, the price is equivalent to the salary and this is a function of the benefit that the reference organization perceives that it can obtain from the subject, from its "value". Logically, the value depends on the characteristics of the product-person, that is, of its human capital (education, knowledge, experience) (Schultz 1962; Mankiw et al. 1992; Savvides, Stengos 2009) and also of their individual social capital (personal attributes and network of contacts of the subject) (Boxman et al. 1991).

\section{Conclusions and discussion}

Social capital is a multidimensional concept that is linked to various economic and non-economic reasons. This article has analyzed the weight of "individual social 


\section{Matias MEMBIELA-POLLÁN et al.GA}

capital" in "personal marketing", within the process of active job search. The social network and the attributes of the subject have a specific weight in the marketing mix instruments, described in the text as: product-person, promotion of the productperson, distribution of the product-person and the price of the product-person.

The adequate combination of these instruments will influence the achievement of personal objectives; which are the promotion of the individual's career and demand by the labor market.

Future research will continue this line of research and will empirically test the relationship between the variables indicated. In particular, and given the high rates of youth unemployment in certain countries, the potential contribution of individual social capital to the performance of human capital within this segment of the population is of great interest.

\section{References}

Acosta Vera J.M. (2006), Marketing personal. El camino al éxito, ESIC Editorial, Madrid.

Adler P.A., Kwon S.W. (2002), Social capital. Prospects for a new concept, „The Academy of Management Review", vol. 27 no. 1, pp. 17-40.

American Marketing Association (1985), AMA board approves new marketing definition, „Marketing News", vol. 1 no. 1.

Belliveau M.A., O'Reilly C.A., Wade J.B. (1996), Social capital at the top. Effects of social similarity and status on CEO compensation, „Academy of Management Journal”, vol. 39 no. 6, pp. 1568-1593.

Bourdieu P. (1986), The forms of capital, in: Handbook of theory and research for the sociology of education, Richardson J. (ed.), Greenwood, New York, pp. 241-258.

Bowles S., Gintis H. (2002), Social capital and community governance, „The Economic Journal”, no. 112, pp. 419-436.

Boxman E.A., De Graaf P.M., Flap H.D. (1991), The impact of social and human capital on the income attainment of Dutch managers, „Social Networks”, vol. 13 no. 1, pp. 51-73.

Burt R. (1992), Structural holds. The social structure of competition, Harvard University Press, Cambridge, MA.

Cameron R., Neal L. (2005), Historia económica mundial. Desde el Paleolítico hasta el presente, Alianza Editorial, Madrid.

Carballar Falcón J.A. (2011), Twitter. Marketing personal y profesional, RC Libros, Madrid. 


\section{INDIVIDUAL SOCIAL CAPITAL AS AN ASSET OF PERSONAL MARKETING}

Coleman J.S. (1988), Social capital in the creation of human capital, „The American Journal of Sociology", vol. 94, supplement, pp. S95-S120.

Fine B. (1999), The developmental state is dead - long life social capital?, „Development and Change”, no. 30 , pp. 1-19.

Glaeser E., Laibson D., Sacerdote B. (2002), An economic approach to social capital, „The Economic Journal", vol. 112, pp. 437-458.

Goleman D. (2010 [2006]), Inteligencia social. La nueva ciencia de las relaciones humanas, Editorial Kairós, S.A, Barcelona.

Guiso L., Sapienza P., Zingales L. (2011), Civic capital as the missing link, in: Handbook of social economics, Benhabib J., Jackson M.O., Bisin A. (eds.), vol. 1A, Elsevier, San Diego, pp. 417-480.

Granovetter M.S. (1973), The strength of weak ties, „American Journal of Sociology”, vol. 78 no. 6 , pp. 1360-1380.

Herrera Echeverri H. (2009), Investigación sobre redes sociales y emprendimiento. Revisión de la literatura y agenda futura, „Innovar. Revista de Ciencias Administrativas y Sociales”, vol. 19, no. 33, pp. 19-33.

Knack S., Keefer P. (1997), Does social capital have an economic payoff?, „The Quaterly Journal of Economics”, vol. 112 no. 4, pp. 1252-1288.

Knoke D. (1999), Organizational networks and corporate social capital, in: Corporate social capital and liability, Leenders R.Th.A.J., Gabbay S.M. (eds.), Kluwer, Boston, pp. 17-42.

Kotler P., Levy S.J. (1969), Broadening the concept of marketing, „The Journal of Marketing”, vol. 33 no. 1 , pp. 10-15.

Kotler P. (2003), Princípios de marketing, Prentice-Hall do Brasil, Rio de Janeiro.

Kotler P., Armstrong G. (2013), Fundamentos de marketing, Pearson Educación, Madrid.

Lambin J.J., Gallucci C., Sicurello C. (2009), Dirección de marketing. Gestión estratégica y operativa de mercado, McGraw-Hill, México D. F.

Leenders R.Th.A.J., Gabbay S.M., Fiegenbaum A. (eds.), Corporate social capital and liability, Kluwer, Boston, pp. 17-42.

Lin N. (1999), Building a network theory of social capital, „Connections”, vol. 22 no. 1, pp. 28-51.

Lin N. (2008), A network theory of social capital, in: The handbook of social capital, Castiglione D., Van Deth J.W., Wolleb G. (eds.), Oxford University Press, New York, pp. 50-69.

Membiela Pollán M. (2016), La teoría del capital social, Editorial Camiño do Faro, S.L., Coruña.

Mankiw N.G., Romer D., Weil D.N. (1992), A contribution to the empirics of economic growth, „The Quarterly Journal of Economics", vol. 107 no. 2, pp. 407-437. 


\section{Matias MEMBIELA-POLLÁN et al.GA}

Millán R., Gordon S. (2004), Capital social. Una lectura de tres perspectivas clásicas, „Revista Mexicana de Sociología", vol. 66 no. 4, pp. 711-747.

Pena López A., Sánchez Santos J.M. (2013), El capital social individual. Lo micro y lo macro en las relaciones sociales, in: Desigualdad y capital social en España, Veira Veira J.L. (ed.), Netbiblo, Oleiros, pp. 11-31.

Pérez Ortega A. (2008), Marca personal. Cómo convertirse en la opción preferente, ESIC Editorial, Madrid.

Putnam R., Leonardi R., Nanetti R. (1993), Making democracy work. Civic traditions in modern Italy, Princeton University Press, New Jersey.

Robison L.J., Siles M.A., Schmid A.A. (2003), El capital social y la reducción de la pobreza, hacia un paradigma maduro, in: Capital social y reducción de la pobreza en América Latina y el Caribe. En busca de un nuevo paradigma, Atria R., Siles M., Arriagada I., Robison Lindon J., Whiteford S. (eds.), CEPAL, Santiago de Chile.

Sánchez Santos J.M., Pena López A. (2005), Actividad asociativa, confianza y generación de capital social. Evidencia empírica, „Ekonomiaz. Revista Vasca de Economía”, no. 59, pp. 136-159.

Santesmases M. (2012), Marketing. Conceptos y estrategias, Pirámide, Madrid.

Savvides A., Stengos T. (2009), Human capital and economic growth, Stanford Economic and Finance, Stanford.

Schultz T.W. (1962), Reflections on investment in man, „Journal of Political Economy”, vol. 70 no. 5, pp. 1-8.

Shepherd I.D. (2005), From cattle and coke to Charlie. Meeting the challenge of self marketing and personal branding, ,Journal of Marketing Management”, vol. 21 no. 5-6, pp. 589-606.

Stanton W.J., Etzel M., Walker B.J. (2007), Fundamentos de Marketing, Mc Graw Hill, México D.F.

Tsai W., Ghoshal S. (1998), Social capital and value creation. The role of intrafirm networks, „The Academy of Management Journal", vol. 41 no. 4, pp. 464-476.

Peters T.J., Waterman R. (2000), 50 claves para hacer de usted una marca, Deusto, Bilbao.

Valarezo Paredes E.F. (2015), Desarrollo de competencias de marketing personal como ventaja competitiva para los futuros profesionales ecuatorianos, Observatorio de la Economía Latinoamericana, no. 209, http://www.eumed.net/cursecon/ecolat/ec/2015/marketing-personal.html [03.11.2018].

Wolleb G. (2008), Introduction. Social capital and economic development, in: The handbook of social capital, Castiglione D., Van Deth J.W., Wolleb G. (eds.), Oxford University Press, New York, pp. 373384. 